\title{
8. A Tale of Two Villages: Hierarchy and precedence in Keo dual organization (Flores, Indonesia)
}

\section{Gregory Forth}

A recent turn in the social anthropology of Austronesian-speaking communities has involved analysis of local social forms with reference to concepts of 'hierarchy' and 'precedence'. In this context, 'hierarchy' more specifically refers to Dumont's notion of 'hierarchical opposition', or 'hierarchical encompassment' $(1979,1980)$, and particularly a version applied by students of Dumont to several Indonesian societies (see for example, Barraud 1979, Barnes et al. 1985, Pauwels 1990; see also Platenkamp 1990, Forth 2001). Deriving from ethnographic studies by Australian-based anthropologists (for example, Lewis 1988; Molnar 2000; McWilliam 2002; Reuter 2002), 'precedence', a social principle conferring higher status on groups considered the older or oldest components of a social and territorial unity, has largely been conceived as an alternative to 'hierarchy' (see Fox 1994), understood as a relation in which two or more components are differentially related to a social whole. Concerning local forms of dualistic social organization, a pattern widespread and evidently ancient in Austronesia, the present paper demonstrates how hierarchy and precedence, rather than denoting distinct or theoretically contrary principles of order, can define different aspects of one and the same order. Comprising a history of relations among clans and villages in the western part of the Keo region of south central Flores, in eastern Indonesia, the case further reveals ways in which particular hierarchical relations have been contested with reference to different local interpretations of precedence. As I show, single groups commonly participate in a series of hierarchical part-whole relations entailing varying degrees of dependence. And insofar as orders of precedence, also, necessarily pertain to particular spatial wholes, changing residential arrangements can involve local groups participating in more than one such order.

As demonstrated elsewhere (Forth 2001), Keo society is pervasively dualistic. In one of very few published references to Keo, that great missionary-ethnographer of Flores, Paul Arndt (1954:19), remarked on the prevalence of what I have elsewhere called 'double settlements' in the region. 'Double settlement' refers to an arrangement in which two villages (nua) are outwardly identical and located adjacent to one another, or at least sufficiently close together to form a palpable pair. While such settlements are indeed typical of Keo, Arndt misconstrued them in two ways. First, he described the settlements 
as single villages divided into two intermarrying halves. Actually, these 'halves' are separate villages, as signalled and defined by each possessing its own sacrificial instrument, or peo - a living tree, forked post or stone column erected in the centre of each village. Secondly, Arndt claimed that the two parts of such settlements (or a pair of villages) were related through a symmetric exchange of women in marriage. In fact, the connection between component villages of a double settlement is thoroughly asymmetrical, in regard to affinal alliance as in other respects.

In one sense, however, Arndt was correct; for in numerous instances, relations connecting paired villages are further reflected within single villages. In part, this replication, or recursion, is attributable to a common historical process whereby over time what were once paired nua have become single nua. Yet in this same process, additional issues of inequality have arisen. As a single village normally possesses a single sacrificial instrument (peo), when two formerly separate groups merge and combine, hierarchy, partly manifest in an order of ritual precedence, must then be realized in relation to this object. Relevant here is the significance of peo as symbols of territorial unity and independence. As the site of collective buffalo sacrificing, the sacrificial instrument is the means whereby component parts of a socio-political whole publicly express and affirm claims to parts of the territory in question and thus membership of groups (clans or villages) that possess and maintain the land, not communally, but in concert (Forth 2001:71-72, 79-81; see also Forth 1989, 1998, on the neighbouring Nage).

\section{Key Features of Keo Social Structure}

While processes of combination necessitate a realization of hierarchical relations, how this is done - that is, how unequal status has been construed or constituted - varies from place to place. In order to shed light on this variation (and the competing local views implicated in it), it is useful to concentrate on a single case. To do so effectively, it will be necessary first of all to review other general details of Keo village society.

Most Keo villages (nua) comprise two or more clans (suku), usually no more than three or four. ${ }^{1}$ Where several groups (which may be clans, or formally separate and locally distinct divisions of a clan, or 'houses') share a single peo, two are always pre-eminent. At the same time, the two are themselves unequal. The seniormost group, or more precisely its male leader, holds the status of 'trunk rider' (saka pu'u) or 'earth breaker' (ta koe). It is he who rides on the trunk (that is, the lowermost) end of a new sacrificial post when the object is carried - trunk end first - into the village. As the second designation would suggest, the leader of the seniormost group is also the first to stab the earth when digging the hole in which to plant a new sacrificial instrument. The precedence of the leading group finds further expression in buffalo sacrificing, since the animal provided by the trunk rider (or earth breaker) is always the first to be killed. 
In all of these respects the leader of the second group, called the 'tip rider' (saka lobo), makes his appearance directly after the trunk rider. In accordance with the local title, he occupies the tip end of a new post (peo). Designated as the 'excavator' ( $t a$ kabhe), this man also scoops up a little of the earth first broken by his more senior partner. Similarly, his buffalo is slaughtered immediately after the animal contributed by the trunk rider (or earth breaker). In collective sacrifices, the buffalo of other groups are then slaughtered, each in a definite sequence decided or affirmed in advance of the ritual. ${ }^{2}$

For the benefit of Indonesianists especially, it should be remarked that the opposition of trunk rider and tip rider does not define or coincide with a contrast of religious and temporal authority. Nevertheless, the two positions - equally religious and equally political - do figure as a major instance of a more general opposition of 'trunk, origin, source' (pu'u) and 'tip' (lobo) operating as a fundamental principle of Keo social order. Closely bound up with their shared relationship with sacrificial posts, trees, or columns, these positions of dual leadership can be assigned on the basis of agnatic seniority within clans. Where a peo is the possession of a single clan $(s u k u)$, the trunk rider will then belong to the seniormost house $\left(s a^{\prime} o\right.$ ) of the clan while the tip rider will be found in the next junior house. Particularly where two previously separate clans have come together in a single village, however, the statuses are usually connected with residential priority, so that the group recognized as having been the first to settle in the village territory, and to have founded the village, is recognized as trunk rider, and thus the principal 'owner' (moi) of a shared sacrificial instrument (peo).

Especially where segments (or houses) of a single clan divide statuses of trunk rider and tip rider, the two positions are distinguished respectively as $\mathrm{ka}^{\prime} \mathrm{e}$, 'senior, elder', and ari, 'junior, younger'. The partial coincidence of this binary relation with that of 'trunk (or source, origin)' and 'tip' is in each case consistent with the temporal precedence of the superior term. Just as a botanical trunk is always older than the tip (or branches), so elder sibling always precedes younger. $K \mathrm{~K}^{\prime} \mathrm{e}$ and $\mathrm{ari}$, however, have a far broader application in Keo social classification than in articulating the asymmetric contrast 'trunk' and 'tip'. When compounded as $\mathrm{ka}^{\prime} \mathrm{e}$ ari, the two terms together denote a reciprocal relationship shared by members of a single clan or of a clan segment occupying a single village; in fact, in its most inclusive sense the compound can refer to any kind of social bond or unity, the parties to which are moreover not necessarily distinguishable as 'senior' and 'junior' (Forth 2001:99-104). In a few instances, the terms are further applied to pairs of distinctly named clans occupying separate villages but recognizing a common origin. Connections between Bale and Bolo, two groups to be discussed presently, provide an instance of this variant of $\mathrm{ka}^{\prime} \mathrm{e}$ ari. 
Besides the opposition of trunk rider and tip rider, residential priority, or temporal precedence, is bound up with another fundamental binary contrast. This is the opposition of 'mother' (ine) and 'child' (ana). Whereas in regard to sacrificial posts (peo) the contrast of 'trunk' ( $p u^{\prime} u$ ) and 'tip' (lobo) is internal to villages, however, the contrast of 'mother' and 'child' is largely external. The main instance of the opposition is the relation of 'land mother' (ine tana) and 'defending child' (ana tuku). ${ }^{3}$ 'Land mother' — or more completely 'mother of the land, father of the stones' (ine tana, ame watu) — denotes the ancestor or group considered to have been the first to occupy and divide a territory among a number of 'children' or 'defenders'. By virtue of this division, all 'defending children' receive the right to found their own villages (nua) and erect their own peo. In the same way, they come to be recognized, or to affirm their status, as members - and prospectively, ancestors - of independent clans. In return the defenders, as their name should suggest, are obliged to assist in protecting the entire territory of the 'mother' against intruders and hence to maintain its boundaries.

As represented in Keo oral history, such transfers of independent rights to land frequently accompanied the marriage of a woman of the land mother clan to a male forbear of a defending group. In this way, the status of 'defending child' (ana tuku) is regularly associated with that of 'wife-taker', a status similarly conceived under a filial rubric as ana weta ('children of sisters'). How far such affinal connections have been perpetuated by way of further marriages over the generations is variable. Furthermore, obtaining wives from another group has by no means always involved simultaneously obtaining rights to land; hence 'wife-taker' is a rather more inclusive category than is 'defending child'.

In response to direct questioning, Keo usually say that the terms 'mother' and 'child' when applied to two clans always specify them as land mother and defender. Yet observation reveals that the contrast of ine and ana is sometimes employed in another, looser way. As demonstrated by the case to be discussed, a group may be described as the 'mother' of another purely on the basis of temporal precedence within a shared territory (a village or double settlement). In such instances, the older group, though it may provide the more recent immigrant with wives and even a share of its land, does not - indeed cannot - grant the latter a sacrificial instrument (peo) of its own. Granting the right to erect a peo to a group that previously did not independently possess a sacrificial instrument is indeed a prerogative of the land mother. On the other hand, where two groups merge to form a single village, the earlier established group usually shares its own sacrificial instrument with the more recent arrival, granting it the right to slaughter, and possibly another ceremonial status (for example, the position of tip rider) as well, while retaining the seniormost position for itself. 
Especially in view of the partial coincidence of 'wife-givers' (moi mame or moi ga'e) and 'land-givers', much of the foregoing will be quite familiar to students of Indonesian societies. But two points are worth stressing. First, while the contrast of 'trunk' and 'tip' and that of 'mother' and 'child' largely pertain to distinct relationships, a certain connection is discernible in an association of wife-givers with the concept of 'trunk', or $p u^{\prime} u$. That is, in Keo, as in other parts of eastern Indonesia, wife-givers are conceived as the trunk, origin, or source of their wife-taking affines (see for example, Barnes 1974, Fox 1980; Forth 1981:286-290, Forth 2001:125ff; Lewis 1988). Secondly, and consistent with these parallels, instances of all three category pairs - trunk and tip, mother and child, and wife-giver and wife-taker — are linked with images implying a relation of whole and part, and hence a subsumption or conceptual encompassment of a subordinate entity by its superordinate partner.

Without rehearsing all ethnographic particulars, we might for example note that a land mother retains nominal dominion over an entire territory, even though parts are formally ceded to 'defending children' who, as a category, are then identified with the boundary or peripheries of the domain. In formal speech, defenders are thus described as 'those who occupy the edge and reside at the end' (ndi'i singi, mera sepu). Noteworthy here is the way in which a whole-part relation is translated into a contrast of centre and periphery. Equally remarkable is the tendency, where two or more clans share a single village, for the oldest and senior group (the 'mother', if not the 'land mother') to be identified with the village as a whole. The clearest expression of this is where the entire village and the oldest clan bear the same name. Thus, in numerous instances, a village named $\mathrm{X}$ contains a clan also named $\mathrm{X}$ as well as a more junior clan named $\mathrm{Y}$ (Forth 2001:84-86, 297-298).

The same part-whole relationship is further evident in the asymmetric affinal connection that is regularly associated with various other non-reciprocal relations. Simply stated, in several ways Keo represent wife-takers as parts of a wife-giving group. To begin with, there is the notion of poro or dhodho which, although both terms translate directly as 'descent' (or 'to go down'), actually refers to inherited affinal connexion, or 'alliance'. It does so by virtue of an identification of a child (ana) with its mother (ine), and hence with the female component of a social whole commonly specified as a house $\left(s a^{\prime} o\right)$. Thus, just as a woman, upon her marriage, 'descends' from her raised, natal house to proceed to the residence of her husband, so Keo envisage her children as having descended with their mother from the wife-giver's house (Forth 2001:130-133). ${ }^{4}$

As mentioned above, Keo history demonstrates how initially separate groups (clans or villages) have amalgamated, forming together single villages. In the course of time, external dualities (including land mother and defender) have thereby become transformed into internal ones. Permitting, even facilitating, 
this process is the conceptual encompassment articulating fundamental binary relations. In some instances, amalgamation occurred after the advent of the colonial period, effectively beginning around 1910. In fact, evidence I review below suggests how institutions of colonial (and subsequent national) administration have affected particular hierarchical outcomes. Nevertheless, it is quite clear from other evidence that recent village amalgamations must be understood as continuing manifestations of a process that is much older and is definitely pre-colonial in origin.

\section{Map 1. Map of Western Keo}

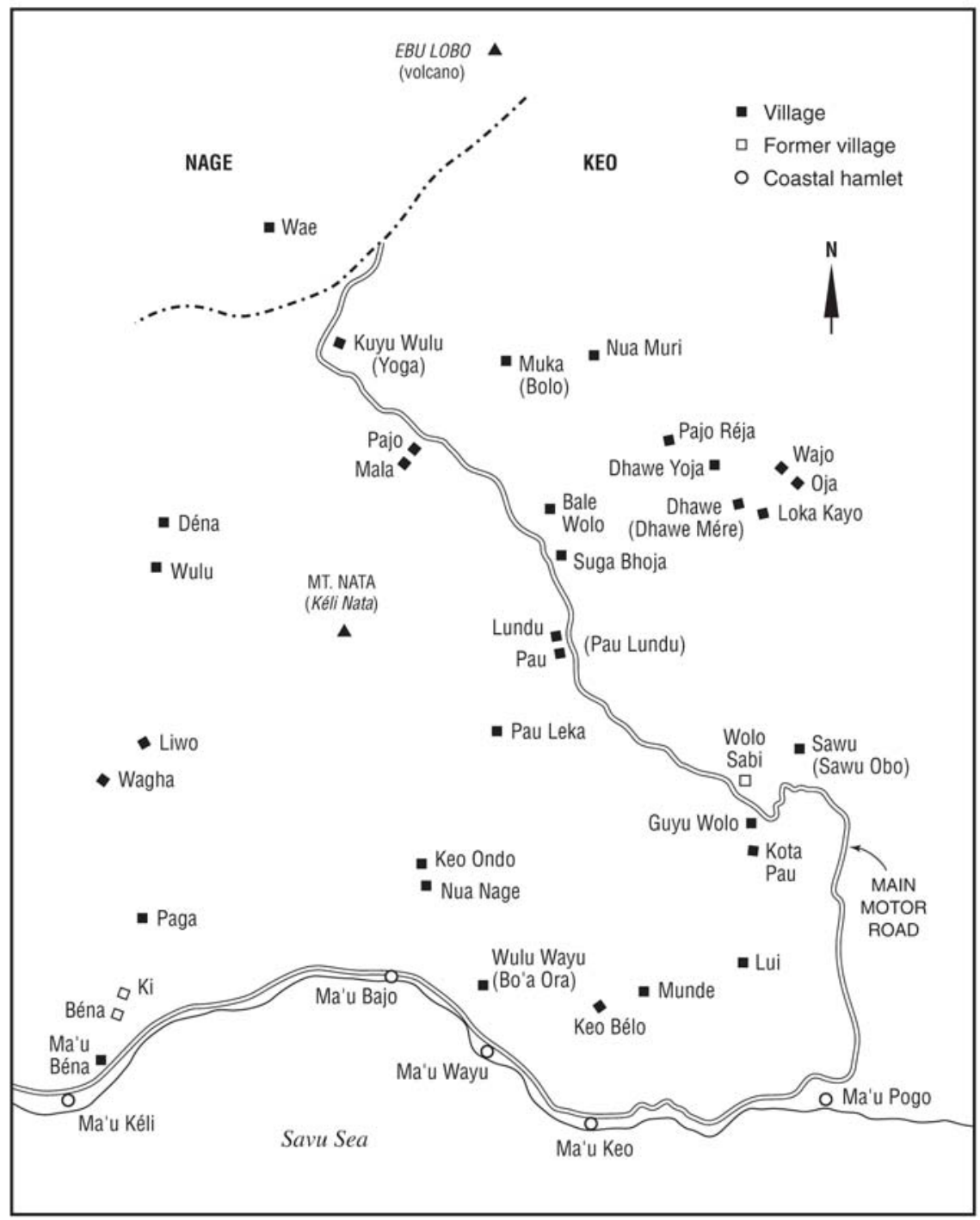




\section{The village of Pajo Wawo (Upper Pajo Mala)}

In what follows I show how historical processes of combination have raised questions, leading to local contestations, of hierarchical order internal to a particular village. With reference to the same case, I also demonstrate how arrangements in place at any given time must be understood as merely the most recent outcome of ongoing competition concerning the application, in particular contexts, of basic principles of Keo social organization. Insofar as dualistic social arrangements form the focus of this analysis, dualism must therefore be understood as a tendency and process and not as a static institutional form.

Figure 1. Stylized plan of the double settlement of Upper and Lower Pajo Mala

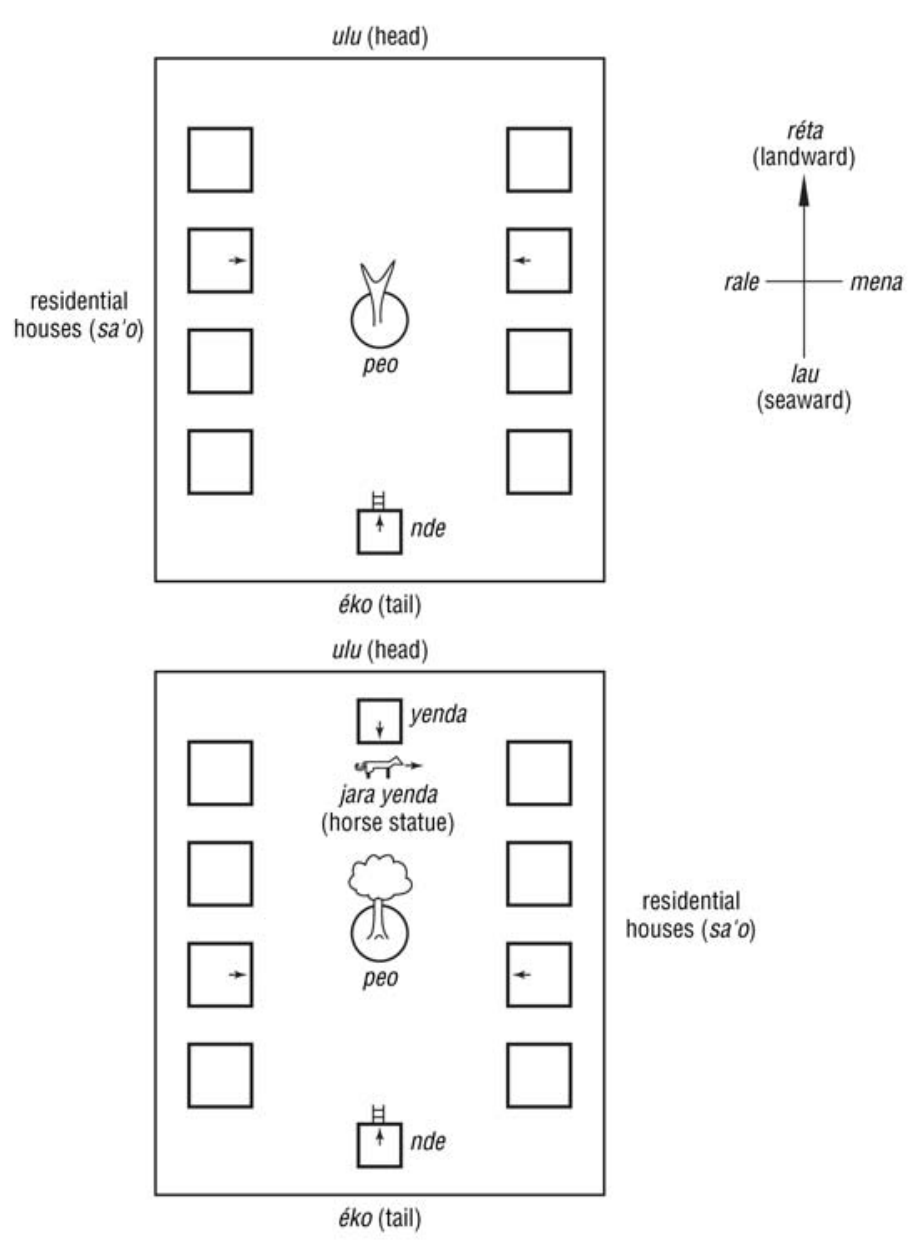

Arrows indicate the direction in which structures face. 
When viewed from the main road that winds above their present sites, the villages of Upper and Lower Pajo Mala might appear the very model of a double settlement (see Figure 1). Possessing a sacrificial instrument (peo) in the form of a stone column, the older village, Lower Pajo Mala (Pajo Au), is located immediately seaward of Upper Pajo Mala (Pajo Wawo), whose centre is marked with a forked wooden peo. According to the usual local representation, each of the two villages contains three clans. The principal clan in the older village is Pajo Wolo ('Hill Pajo'), a group that appears to have lent its name by antithesis to the whole village and hence to the entire double settlement (Pajo Mala, 'Pajo of the Plain'). It is joined by clans Kayo (or Pajo Kayo) and Bindi Wae. ${ }^{5}$ The trio inhabiting Upper Pajo Mala consists of clan Kate plus the Upper and Lower divisions of a group called Bale, each of which is recognized as a separate clan. At the same time, Upper and Lower Bale together are sometimes described as a single 'clan', and in other ways as well the two groups compose a unity combining dualistically with Kate.

Despite appearances, both the manifestly binary combination of Lower and Upper Pajo Mala and their formal symmetry are relatively new, having originated in the colonial period just 80 to 90 years ago. Before this, Lower Pajo Mala which was then the only village named Pajo Mala - stood alone. At this time, Kate and the two divisions of Bale were resident some distance to the west, in another double settlement named Kate Bale.

The history of Kate Bale and its transformation into Upper Pajo Mala is the main focus of this paper. In what is virtually the only colonial report providing detailed and substantial information on indigenous social organization in the administrative region that came to be known as 'Nage Keo', in 1940 the Dutch official Louis Fontijne described the clan Kate as the earliest known group to inhabit the southern part of the Nage district of Wolo Wea (Forth 2004). From there, the ancestors of Kate several generations previously had been driven out of their original villages of Wolo Kate and Kate Kela by their enemies, the ancestors of Kéli Mado, another Nage domain, located to the south of Wolo Wea. Fleeing from their villages of origin, the Kate people moved further south and westwards, towards the western part of Keo where their present descendants are now found in the village of Upper Pajo Mala.

While Fontijne says no more than this, his report corresponds in all essentials to the history of Kate as told to me by Kate people in the 1990s. After arriving in Keo, the Kate leader, Léwa Dhéma, settled temporarily on land belonging to clan Bindi Wae, one of the present inhabitants of Lower Pajo Mala. Following one version of the Kate genealogy, Léwa Dhéma took a wife from Bale (specifically the clan Upper Bale), who were already settled in the vicinity in a village called Nua Bale ('Bale Village') or One Bale (one is 'inside, interior', and can thus mean 'place of'). Other evidence suggests that marriages between Kate and Bale began 
two generations after Kate's arrival. Whatever the precise details, an early union between a Kate man and a Bale woman initiated an asymmetric affinal alliance between the two groups that has since been perpetuated by at least seven further marriages. Kate genealogies show Léwa Dhéma living eight generations prior to the present Kate leader, a man now in his seventies. If a generation is estimated as 25 to 30 years, the removal of the Kate people to western Keo would therefore appear to have occurred between 200 and 300 years ago.

Connected with Kate becoming a wife-taker of Bale - either as precedent or antecedent - Mepe Lape, the son of Léwa Dhéma, moved with other Kate people to a new site near the village of the Bale people (Nua Bale). Since wife-givers are often also land-givers, it should be stressed that Kate did not receive land from Bale. Rather, in addition to plots previously obtained from the clan Bindi Wae, Kate acquired rights to further areas of land within the territory of Lape, the seniormost 'land mother' in the whole of western Keo. At the same time, Kate people describe their ancestors as having obtained land from Lape with the support and mediation of Bale. The land in question had initially been assigned to Pajo Wolo, one of the most important 'defending children' of Lape and the leading clan in Lower Paja Mala. Upon founding its own village, the Bale group also had acquired lands within the domain of Lape. Hence, in regard to territorial rights, Kate and Bale were, and remain, generally of equal standing. After founding a double settlement with Bale, the new village established by Kate was simply named Nua Kate ('Kate Village') and the entire settlement was designated, in a typically binary fashion, as 'Kate Bale'.

Owing to its prior occupation of the older half of Kate Bale, the Bale group (which as noted nowadays comprises two clans) is commonly described as the 'mother' while Kate, the latter arrival, is accordingly the 'child'. Bale is not however considered land mother in relation to Kate. That status is occupied in relation to Bale as well as Kate - by the clan of Lape, although in certain contexts it is Pajo Wolo, as the principal 'defending child' of Lape in this part of Lape's ancestral territory, that is so designated. ${ }^{6}$ As the foregoing reveals, while Bale was older than Kate in Kate Bale, both groups are relatively recent arrivals in western Keo. Bale in fact represents the most recent of several waves of immigration from Ola Bolo ('Place of Bolo'), a settlement located in what is now the eastern part of the Ngadha district. Earlier immigrants from Ola Bolo were a group that retained the name Bolo and which at present resides in the village of Muka (also known as Bolo), some distance landward of Upper Pajo Mala. Like Bale, Bolo too comprises a pair of clans, similarly distinguished as Upper Bolo (the more senior group) and Lower Bolo. ${ }^{7}$ In respect of their common geographical origin in Ola Bolo, the two clans of Bale and the two of Bolo together compose a grouping known as 'Bolo Bale'. Within this non-localized dualistic whole, Bale is the junior component and, in ways I describe presently, is still politically and ritually subordinate to Bolo. Indeed, Bolo and Bale continue to 
operate in certain contexts as a single corporate entity, even to the extent of assigning heirs, when necessary, to houses and estates of the opposite group. Moreover, insofar as Bolo tends to be identified with the whole which is named 'Bolo Bale', it would not be inaccurate to describe Bale as a junior segment of Bolo. $^{8}$

Also relevant in this connection is a period of co-residence with Bolo, after Bale first arrived in western Keo, in an earlier village also named Bolo (or, more completely, Bolo Ndata). Later, the Bolo group founded another village, adjacent to the village of Yoga, thus forming a double settlement known as Bolo Yoga, and about the same time Bale removed some distance landwards to establish its own village of Nua Bale. As noted, in order for a village to be ceremonially complete and independent it must possess a sacrificial instrument (peo). By all indications, however, the Bale people, while residing alone in Nua Bale, did not possess a peo of their own. Indeed, they appear to have first erected such an object only when they founded Upper Pajo Mala, just 70-odd years ago. Although this settlement is spoken of as Nua Bale, this circumstance thus casts some doubt on its formal status as a nua, or 'village'. At the same time, Bale's lack of a sacrificial instrument (peo) is quite consistent with the group's continuing subordination to Bolo, a matter to which I return in a moment.

Especially in regard to its sacrificial status, Kate's circumstances upon arriving in western Keo were quite different from Bale's. One version of the clan's genealogy indicates that Kate erected a peo in its own separate village of Nua Kate just two generations after settling there. As this would suggest, the paired statuses of trunk rider and tip rider connected with the sacrificial instrument were then both occupied exclusively by men of clan Kate, which by this time had bifurcated to form two separate 'houses', one identified with the trunk rider and the other with the tip rider. Indeed, as trunk and tip riders must always come from separate houses and estates, Kate's erecting and inauguration of a peo was likely the occasion of this bifurcation. Reckoning genealogical time in the way specified earlier, the evidence suggests that Kate erected their peo sometime in the early or middle part of the nineteenth century.

Since several kinds of sacrificial instruments are in use in the Keo region, it is important to note that the peo Kate claim independently to have erected in Nua Kate was a peo yebu, a carved forked post of Cassia wood yebu, Cassia fistula). As this is the sort employed throughout the Nage region, Kate's claim to rightful possession of such a post thus agrees with the clan's geographical derivation from southeastern Nage. Although resident in an immediately adjacent settlement, the Bale people never slaughtered buffalo at Kate's post; if ever they did so it was only as invited guests and not as a matter of right. Within their own former village of Nua Bale, in order to affirm their independent ownership of land Bale performed sacrifices without the aid of a peo by employing only 
yaka and ia, structures after which the two divisions, or clans, of Bale are still regularly named. ${ }^{9}$ As subordinates of Bolo, moreover, Bale were obliged to participate in buffalo sacrifices in the village of Bolo.

The evidence of local history thus indicates that, within the double settlement of Kate Bale, the clan Kate enjoyed not only ceremonial independence from Bale but, since only they possessed a peo, a kind of superiority as well. Towards the beginning of the twentieth century, however, relations between Kate and Bale underwent a fundamental change. At this time, people of Kate Bale began moving to the site of what is now Upper Pajo Mala. The first to do so were people of Bale, whose previous village (Nua Bale) had suffered serious damage in a landslide sometime after 1910. Kate moved later. Following local estimates, the entire move was completed, and Kate Bale became entirely abandoned, around 1927. Before this time, the site of Upper Pajo Mala had been a hamlet (bo'a) containing field houses belonging to people of Lower Pajo Mala and was ceded to Bale and Kate by the leading clan in the lower village, Pajo Wolo.

In accordance with the relative disposition of the former Nua Kate and Nua Bale within the double settlement, upon moving to Upper Pajo Mala the Kate people built their houses towards the seaward end of the settlement, while Bale settled at the landward end. It must be stressed, however, that with this move, what had previously been two villages (nua) — Kate and Bale — became a single village. On the other hand, by locating the settlement just above Pajo Mala, which subsequently became Lower Pajo Mala, the new village became part of another dual combination in which Kate and Bale together were subordinated to the earlier established member of the pair — Lower Pajo Mala (Pajo Au).

To understand the subsequent course of events, it must first be noted that the movement of Kate people to Upper Pajo Mala and their amalgamation with Bale was encouraged by local leaders appointed by the colonial administration. Prominent among these was Lowa Bule, the 'major mandur' (mando mére) of the colonial subdistrict which included both Kate Bale and Pajo Mala. ${ }^{10} \mathrm{~A}$ man of the clan Bo Bana in the village of Pau Lundu (located several kilometres seaward of Pajo Mala), Lowa Bule was a wife-taker of Bale, more specifically of Lower Bale (Bale Au). Largely in his position as 'mandur', the same man was also influential in the decision, taken not long after 1927, to erect a forked sacrificial post (peo) in Upper Pajo Mala. To obtain such a post, goods conceived as a bridewealth must be given to the owner of the land where the symbolically feminine tree is cut. Both Bale and Kate contributed to this bridewealth, with Bale supplying a buffalo, and Kate a pair of gold ornaments and a knife. Kate and Bale thereby both obtained rights in the sacrificial post. For reasons already explained, however, the two groups would necessarily share in the post unequally. 
So it was that a forked peo of Cassia wood was obtained and erected in Upper Pajo Mala in 1929. But before this could be done, decisions had to be taken as to who would serve as trunk rider and who as tip rider. Citing the fact that only they had possessed a peo in the previous settlement of Kate Bale, and moreover a forked post of precisely the same kind as the one to be erected, people of clan Kate claimed that they should occupy both positions. In addition, and by virtue of this possession, the clan was already divided into segments identified with the two ceremonial statuses. In the event, however, and with crucial support from the aforementioned Lowa Bule, the people of Bale successfully claimed that men of their group should be recognized as riders of both the trunk and the tip of the new peo. In this arrangement, the division of Bale into Upper and Lower clans came into play, with Upper Bale, the senior group, occupying the position of trunk rider. According to one local formulation, then, what had previously been the peo of Kate (in Kate Bale) became the peo of Bale. Worth noting in this connection is the fact that the post planted in 1929 - like its replacement, erected in September 1991 - is still referred to as the peo of Kate Bale, a name that in fact is still occasionally applied to the modern village of Upper Pajo Mala.

According to another argument, advanced by Kate people when I discussed the matter with them in the 1990s, while Upper Bale acquired the position of trunk rider in 1929, both Lower Bale and Kate were jointly recognized as tip rider. In regard to the shape of the forked post - consisting of a single trunk but two branches - this interpretation has a certain plausibility. Nevertheless, it controverts the consistently dualistic form of ritual organization relating to any peo, and for this reason was rejected by others involved in the debate.

Bale's claim to both the trunk and the tip of the sacrificial post erected in 1929 is less explicitly rationalized than the unsuccessful counter-claim of Kate. Even so, it is clear that Bale's earlier occupation of Upper Pajo Mala counted in their favour, as did the fact that they were settled in Nua Bale before Kate people founded Nua Kate. But Bale's right to erect a forked peo of Cassia wood, the same sort previously possessed by Kate, is less firmly grounded. Implicitly, it is based on a conception of the peo in Kate Bale, more precisely in Nua Kate, as a joint possession of both Bale and Kate, reinforced by a view of Upper Pajo Mala as the successor of the double settlement. According to a more explicit, and quite different, local interpretation, by erecting a forked post Bale were merely following the precedent of their senior relatives, the group called Bolo, who had erected a peo of the same kind in the village of Muka sometime before this, probably early in the twentieth century. In fact, in relation to their own peo, the Bolo people regard the forked post in Upper Pajo Mala as a 'branch peo' (peo taya), that is, one that has 'grown out of' and is subsidiary to the peo belonging to Bolo. 
This connection with Bolo, however, raises another contentious issue, namely, whether Bale, being subordinate to Bolo, was fully justified, in 1929, in erecting a peo of any sort. Kate's position on this point goes without saying. But there is yet another twist. Some local sources argue that Bolo itself had no obvious right to employ a forked Cassia wood peo, since prior to their removing to Muka, Bolo had possessed a sacrificial instrument of another sort - a living kesi tree, a peo muri ('living peo') planted in the centre of Bolo's section of the former double settlement of Bolo Yoga. Whatever force temporal precedence may have had in advancing Bale's claim to the primary positions of trunk and tip rider, moreover, it appears that what was crucial to its realization was the involvement of an outsider, Lowa Bule, whose influence partly derived from his occupying an administrative position completely foreign to the cultural framework in which decisions regarding the hierarchical positioning of individuals and groups in relation to sacrificial posts are traditionally taken.

If Bale's claim was compromised by its subordination to Bolo, Bolo in turn remains subordinate to clan Yoga (in the context of the former double settlement of Bolo Yoga), which is one of the principal 'defending children' (ana tuku) of land mother Lape. Viewed in this way, Bale is as it were three times subordinated. And by the same token, the clan is at least twice subsumed - in Bolo Bale and thence in Bolo Yoga. Kate, on the other hand, has the hypothetical advantage of having come to western Keo out of a socio-political and cultural 'nowhere', successfully maintaining along the way, or at least until its removal to Upper Pajo Mala, a major symbol of independence, a forked peo, originating in its country of origin. In this regard, then, Kate need recognize the ceremonial precedence only of the land mother, Lape. And insofar as Kate's peo was not in fact granted by Lape, they need recognize the ceremonial precedence of no one at all.

Characteristically, Keo villagers point to physical objects as 'evidence' (usually expressed with the Indonesian term 'bukti') of historical processes and their outcomes in present-day social configurations. While Bale may have been able in 1929 to erect a peo, the continuing subordination of Bale to Bolo is visibly manifest in the absence of a ceremonial building called yenda, which one might expect to find at the landward extremity of Upper Pajo Mala. Present in all villages with a claim to be truly complete and fully independent in sacrificial matters, the yenda is a building adorned with a wooden horse statue (jara yenda; see Figure 1) and used to store the skulls and horns of buffalo sacrificed at the peo. As a structure thus complementary to a sacrificial post, in parallelistic speech the former is named together with the latter, as peo yenda.

As the junior component of Bolo Bale, however, even today the Bale people are obliged to take the heads of buffalo they slaughter in Upper Pajo Mala to the village of Muka. Once reduced to horns and skulls, these are then placed in 
the yenda belonging to Bolo. Kate, on the other hand, is under no such obligation. Horns and skulls of buffalo they slaughter are stored in a similar building called $n d e$, which stands at the seaward end of Upper Pajo Mala and replaces another structure of this sort formerly maintained by Kate in Nua Kate. Since trophy horns are normally kept in yenda, the nde being used for other purposes, this practice of Kate's is somewhat irregular. Yet it makes perfect sense in respect of the relationship between Kate and Bale since the establishment of Upper Pajo Mala, as well as in the context of Bale's continuing dependence upon Bolo.

In 1991, a further revision of these relationships took place. By this time the peo erected in 1929 was badly rotted, and it was decided that a replacement had to be found. ${ }^{11}$ As always when people need to obtain a new peo, all interested parties had to review the question of who should serve as trunk rider and who as tip rider. Without going into detail, it may be sufficient to note that, by this time, the clan Kate had recovered some of the political ground it had lost to Bale in, or sometime before, 1929. When I first discussed the matter with them, Kate people were still claiming that, by rights, it was they who should occupy the position of trunk rider, and that the most Bale could claim was the position of tip rider. Yet they were apparently willing to compromise; and in the event the tip was ridden by Kate and the trunk by Bale (specifically Upper Bale). Thus whereas, previously, Bale had gained control of both principal positions associated with the sacrificial post, now one at least, the junior of the pair, had been assigned to Kate.

Since I have already demonstrated how the presence or absence of physical objects can serve as a visible sign of the status of a settlement and internal relations among its component groups, it should further be noted how the revision of relations between Bale and Kate in 1991 finds expression in the outward form of the new peo post, more particularly in certain items ancillary to the wooden structure. Prior to 1991, at the base of the old post and atop the platform of stones that surrounded it, were planted three short upright stone pillars called ia (like the object always planted seaward of a peo).These represented the three clans that composed Upper Pajo Mala, and that were able to sacrifice at the post as a matter of right, namely, Upper Bale and Lower Bale (the trunk and tip rider respectively) and Kate. After the new peo was erected, however, four upright stones were erected around the post. What is more, the new stones were explained not with reference to component clans, but to the ceremonial positions associated with the post. Specifically, two stones represent the trunk and tip riders, thus respectively Upper Bale and the senior segment of Kate, while the other two are identified with Lower Bale and a more junior segment of Kate (specified as occupants of two lesser ceremonial statuses that figure in rites performed when obtaining a new peo; see Forth 2001:62 note 9). The stone identified with the trunk rider, Upper Bale, is noticeably larger than the other three; in addition, being located on the landward side (or towards the 
'head' of the village) and on what is arguably the right side of the peo post, it also occupies a position superior to the other three stones. Nevertheless, whereas Kate previously appeared as a poor third within the triad of clans occupying Upper Pajo Mala, as the new set of stones attests Kate has achieved a kind of numerical parity with Bale, even though the clan remains subordinate to Upper if not to Lower Bale.

\section{Conclusion}

Ongoing competition between Bale and Kate reveals the importance of temporal precedence - who arrived in a place first - in determining hierarchical relations within dualistic wholes in western Keo. Bale's main claim to a superordinate position in relation to Kate rested largely, and reasonably securely, on its having been the older component of the double settlement named Kate Bale, and indeed the first to arrive in the village of Upper Pajo Mala as well. Yet simple chronological priority is not always sufficient to ensure precedence in a fuller sense. In Keo, precedence rests on establishing a part-whole relation in which the superordinate member of a pair or series is first (or original) in relation to a clearly defined whole. In this regard, Bale suffers from two weaknesses. First, when joined by Kate to form Kate Bale, Bale was not the principal group within the wider territory in which Kate was subsequently included. Indeed, the lands that made up the domain of Kate Bale derived from other sources and from other groups exercising prior claims. Secondly, Bale appears to have been unable to claim precedence in relation to the whole of Kate Bale owing, at least in part, to its continuing subordination to - indeed, its encompassment by - yet another group, namely Bolo. As shown with reference to the structure called yenda, ceremonial incompleteness in Keo can signal a group's standing as a subordinate part of a whole external to the village. 'Wholeness' might therefore be described as a precondition for superordinate status or, equating hierarchy with encompassment (as does Dumont 1979), identification with another kind of 'whole'.

In Keo society, hierarchy, understood as a part-whole relation wherein a greater part conceptually subsumes a lesser, normally coincides with precedence, conceived in the first instance as chronological priority. Yet, as in the case just reviewed, the two values can sometimes figure as competing principles in determining relationships that can be conceived in terms of either hierarchy or precedence. In both Kate Bale and Upper Pajo Mala, Bale was first (and in this respect could claim precedence). Yet in relation to neighbouring groups, Kate has always been less encompassed than Bale, and thus less subordinated.

Bale's incompleteness and subordination to Bolo bears on another feature of Keo traditional order highlighted by the present case. Often, localized dualities can only be understood in relation to long-standing connections with groups outside of villages or double settlements, or what, as the grouping called 'Bolo 
Bale' exemplifies, may be described as non-localized dualities. In other words, a group (usually specifiable as a 'clan') can participate in a number of dualisms of varying contextual relevance which are nevertheless potentially connected one with another. At a conceptual level, this connection corresponds to the overlap, or partial coincidence, of such widespread Austronesian category pairs as 'mother/child' (ine/ana), 'trunk/tip' (pu'u/lobo), 'elder/younger' (ka'e/ari), and 'wife-giver/wife-taker' (moi mame/ana weta). At the same time, how relations between actual social groups - often reflecting processes of combination rather than bifurcation - are at any given time interpreted in reference to these contrasts may reflect political forces and processes that are relatively independent of this conceptual order, and are based upon other values.

\section{References}

Arndt, Paul SVD

1954 Gesellschaftliche Verhaltnisse der Ngadha. Studia Instituti Anthropos Vol. 8. Wien-Mödling: Verlag der Missionsdruckerei St. Gabriel.

Barnes, R.H.

1974 Kédang: a study of the collective thought of an eastern Indonesian people. Oxford: Clarendon Press.

Barnes, R.H, Daniel de Coppet, and R.J. Parkin (eds)

1985 Contexts and levels: anthropological essays on hierarchy (JASO Occasional Papers No. 4). Oxford: JASO (Journal of the Anthropological Society of Oxford).

Barraud, Cécile

1979 Tanebar-Evav: une société des maisons tournée vers le large. Cambridge: Cambridge University Press/Paris: Editions de la Maison des Sciences de l'Homme.

Dumont, Louis

1979 The anthropological community and ideology. Social Science Information (Sage: London and Beverly Hills) 18(6):785-817.

1980 Homo hierarchicus: the caste system and its implications. Complete revised English edition. Chicago: The University of Chicago Press.

Forth, Gregory

1981 Rindi: an ethnographic study of a traditional domain in eastern Sumba. Koninklijk Instituut voor Taal-, Land- en Volkenkunde, Verhandelingen 93. The Hague: Martinus Nijhoff. 
1989 The pa sése festival of the Nage of Bo'a Wae (central Flores). In C. Barraud and J. Platenkamp (eds), Ritual and socio-cosmic order in eastern Indonesian societies. Part I, Nusa Tenggara Timur. Bijdragen tot de Taal-, Land- en Volkenkunde 145(4):502-519.

1998 Beneath the volcano: religion, cosmology and spirit classification among the Nage of eastern Indonesia. Koninklijk Instituut voor Taal-, Land- en Volkenkunde, Verhandelingen 177. Leiden: KITLV Press.

2001 Dualism and hierarchy: processes of binary combination in Keo society. Oxford: Oxford University Press.

2004 Guardians of the land in Kelimado: Louis Fontijne's study of a colonial district in eastern Indonesia. Edited and translated by Gregory Forth with the assistance of Han F. Vermeulen. Leiden: KITLV Press.

Fox, James J.

1994 Reflections on 'hierarchy' and 'precedence'. In M. Jolly and M. Mosko (eds), Transformations of hierarchy: structure, history, and horizon in the Austronesian world. History and Anthropology (Special Issue) 7:87-108.

Fox, James J. (ed.)

1980 The flow of life: essays on eastern Indonesia. Cambridge, MA: Harvard University Press.

Lewis, E.D.

1988 People of the source: the social and ceremonial order of Tana Wai Brama on Flores. Verhandelingen van het Koninklijk Instituut voor Taal-, Landen Volkenkunde 135. Dordrecht, Holland/Providence, USA: Foris Publications.

McWilliam, A.R.

2002 Paths of origin, gates of life: a study of place and precedence in southwest Timor. Verhandelingen van het Koninklijk Instituut voor Taal-, Landen Volkenkunde 202. Leiden: KITLV Press.

Molnar, Andrea K.

2000 Grandchildren of the Ga'e ancestors: social organization and cosmology among the Hoga Sara of Flores. Koninklijk Instituut voor Taal-, Land- en Volkenkunde, Verhandelingen 185. Leiden: KITLV Press.

Pauwels, Simonne

1990 From Hursu Ribun's 'Three hearth stones'. In C. Barraud and J. Platenkamp (eds), Ritual and socio-cosmic order in eastern Indonesian societies, Part II, Maluku. Bijdragen tot de Taal-, Land-en Volkenkunde 146(1):21-34. 


\section{Platenkamp J.D.M.}

1990 The severance of the origin: a ritual of the Tobelo of North Halmahera. In C. Barraud and J. Platenkamp (eds), Ritual and socio-cosmic order in eastern Indonesian societies. Part II, Maluku. Bijdragen tot de Taal-, Land-en Volkenkunde 146(1):74-92.

Reuter, T.A.

2002 The house of our ancestors: precedence and dualism in highland Balinese society. Koninklijk Instituut voor Taal-, Land- en Volkenkunde, Verhandelingen 198. Leiden: KITLV Press.

\section{ENDNOTES}

1 Derived from Malay, suku is the term Keo most often use for 'clan', even when speaking their own language. Reputedly older terms (which at present have more currency in other parts of central Flores) are woe and 'ili woe. Affiliation to clans is normally patrilineal, with the majority of men paying bridewealth to the wife's clan and thereby securing the incorporation of children to their own clan.

2 This description is necessarily condensed. Trunk rider and tip rider refer specifically to functionaries connected with forked posts of Cassia wood. Earth breaker and excavator on the other hand are the equivalent positions when a living tree or stone column is employed as a peo. However, when a forked peo is erected, the trunk rider serves as earth breaker as well. In accordance with the case discussed below, I hereafter speak only of trunk rider and tip rider.

3 'Defending child' is mostly a convenient gloss. Tuku means to 'shut off, out' and 'to bar, dam (up)', thus conveying the image of a protective barrier. As Austronesianists will recognize, ana has a wider range of meanings than 'child', generally conveying ideas of subordination, relative smallness, and membership of a collectivity.

4 Ana weta are thus not just 'children' of 'sisters'; they are in a definite sense also 'children' of the wife-giving group, and belong to it by virtue of their relation to the group's female members who retain a connection to their natal house. In the expression ana weta, moreover, ana ('child') refers not just to offspring but to 'descendants' of (or through) women (Forth 2001:115-117).

5 Bindi Wae is itself a dual composition, comprising Bindi and descendants of its wife-taker, a segment of the clan Wae.

6 The clan of Lape, the foremost ancestor, is actually called Céla, but it is more usually the ancestor, Lape, rather than his clan that is specified as the land mother.

7 Like Upper Pajo Mala, the village of Muka (Bolo) also includes a third (and in this case decidedly subordinate) group: the clan Suga. In fact, it is quite usual in Keo to find settlements locally represented as comprising two groups but which nevertheless include a third and sometimes a fourth separately named component (Forth 2001:301-303).

8 Bale men publicly and formally introduce themselves as 'Bolo Bale' when they slaughter buffalo in Muka, the present village of the Bolo people. Keo sometimes refers to Bolo Bale as a 'clan' (suku). The usage illustrates the relativity of the concept of $s u k u$, which as noted is also applied to the two divisions of Bale conceived as a unity. The same relativity characterizes nua ('village'), used both for single villages and for double settlements comprising two villages.

9 Yaka denotes a bamboo lattice erected seaward of a sacrificial post, column, or tree. It is through the yaka that the tethers of sacrificial buffalo are placed. Ia refers to a vertical stone or stake erected on the landward side of a peo, to which the ends of the tethers are tied. Upper Bale (Bale Yape Wawo) is thus alternatively known as Bale Yape Ia, and Upper Bale (Bale Yape Au) as Bale Yape Yaka.

10 'Mandur' is usually translated as 'foreman'. In central Flores, 'major mandur' referred to a native official assigned to execute the orders of the native headman of a sub-district.

${ }^{11}$ Whereas peo of Cassia wood can last up to a century or longer, this post had deteriorated considerably by the 1980s, just 50 years after it was cut. Villagers attributed this lack of durability to the tree having been too young and too small, a circumstance which suggests that the 1929 peo, perhaps connected with the controversy surrounding its installation, was obtained in haste. 